\title{
FLAVIN COMPOUND IN FROG' EYE
}

\author{
KUNIO YAGI* \\ Department of Biochemistry, School of Medicine, Nagoya University
}

In 1934, Euler and Adler (1) recognized that a large amount of flavin compound was contained in retina of certain fishes and all of it was dialysable through collodium membrane, and stated that the fluorescence of flavin compound in the retina might have some connection with visual senses. Karrer and Fritsche (2), by their fluorescence-gauging curve of flavin compound, considered that the fluorescence of flavin compound in the retina intensified the visual senses. Brunner and Baroni (3) found that the absorption spectrum of the flavin compound contained in the retina corresponeded to that of lactflavin, and that by cataphoresis this flavin compound was not found to be an ester of phosphoric acid. Euler and Adler (4) reexamined this problem using benzyl alcohol and emphasized that the flavin compound in the retina is free riboflavin, and not an ester of phosphoric acid. Consequently it does not take part in the respiration of the retina but in the visual action because of its fluorescence. Sullmann (5) found that flavin compound accelerated the oxidation of pyruvic acid in the retina, but he did not mention any enzymatic action, believing that flavin compound acted only optically.

On the other hand, Nakashima (6) and Kubowitz (7) clearly demonstrated that the retina conducted an exeedingly vigorous respiration. Fleischmann et al. (8) reported that the flavin compound had a favourable influence on the respiration of the retina of rabbits inhibited by cyanic acid. It seems therefore quite possible, in spite of the opinions of the above mentioned investigators, that the flavin compound acts as co-enzymes in the retina.

From this point of view, experiments were made to determine the significance of its flavin compound. As a first step, an attempt was made to investigate (a) the distribution of flavin compound in the eyes, (b) its change at different seasons, (c) the attitude of flavin compound when the eye is exposed to light, and (d) in what condition this flavin compound exists in the retina.

In regard to the distribution of flavin compound in the eye, investigations were made by Manabe (9), Takada and Nagamura (10) on various animals and cod-fish, but concerning frogs, Manabe has reported only on some cases of toads (Bufo vulgaris formosus).

\section{MATERIALS FOR STUDY AND METHODS OF MEASUREMENT}

Rana nigromaculata, Rana catesbiana, Rana rugosa, Rana japonica, and Bufo vulgaris formosus were used.

After the eyeball was excised at the equater, the retina was picked up with

Received for publication April 17, 1951.

*八木國夫 
its edge by means of a pair of small hooked forceps. The aqueous humour in the anterior chamber and vitreous body was collected by puncture. It was easy to take out the other parts separately, but the pigment attached on the sclera was to be removed carefully.

The so-called "lumiflavin fluorescence method" was used for determining the total quantity of flavin compounds. To extract flavin compounds from the tissues, the method of "warm-water-extraction" (11) was employed. The procedure was as follows : pieces of fresh tissue were excised, immersed in water at $80^{\circ} \mathrm{C}$. for 5 minutes, ground by a homogeniser and kept at $80^{\circ} \mathrm{C}$. for 15 minutes. By the above procedure flavin compounds could be extracted completely from animal tissue without undergoing hydrolysis or decomposition.

The quantity of flavin compound in this extract was measured as follows : (a) an aliquot of the extract was taken and the same volume of $\mathrm{N}-\mathrm{NaOH}$ was added to it, (b) the above mixture was exposed to an electric lamp of $200 \mathrm{~W}$ for 1 hour to convert flavin compound into lumiflavin, (c) the above mixture was acidified by adding glacial acetic acid, (d) the lumiflavin was extracted from it with chloroform, (e) and the intensity of fluorescence of the chloroform was compared with that of a standard lumiflavin chloroform solution. Standard lumiflavin chloroform solution was made from an aqueous solution of standard ribollavin by the same procedure.

For determining whether flavin is free riboflavin or flavin mononucleotide (FMN) or flavin adenine dinucleotide (FAD), its solubility in benzyl alcohol was examined. According to Emmerie (12), free riboflavin is soluble in benzyl alcohol, but its ester is not.

Simultaneously, a qualitative analysis of flavin compound by filter paper chromatography $(13,14)$ was conducted. The procedure was as follows: (a) the flavin compounds in the tissues were extracted by "warm-water-extraction," (b) the extract was saturated with ammonium sulfate, and protein removed by filtration, (c) the flavin compounds in this filtered solution were extracted with water-saturated phenol, and returned to water by the addition of ether to the phenol layer, (d) the aqueous solution of concentrated flavin compounds was placed on a filter paper, (e) after they are developed with $n$-butyl alcohol acetic acid mixture, each of the flavin compounds separated on the filter paper was observed by their characteristic yellow-green fluorescence with ultra-violet ray (as $\mathrm{Rf}$ value, free riboflavin is $0.3, \mathrm{FMN}$ is 0.09 , and FAD is 0.02 ).

\section{RESULTS}

1. Distribution of flavin compound in the eye of Rana nigromaculata. Distribution of flavin compound (calculated as free riboflavin) in the eyeball of this frog in summer is shown in table 1.

None of the flavin compound, both in the aqueous humour of anterior chamber and in the lens could be recognized. It is probable that flavin compounds do not exist in the vitreous humour. Its presence in minimal quantity found in it is probably due to contaminations with injured tissues. 
Table 1

\begin{tabular}{|c|c|c|c|c|c|}
\hline & \multirow{2}{*}{$\begin{array}{c}\text { Number } \\
\text { of } \\
\text { pieces }\end{array}$} & \multicolumn{2}{|c|}{$\begin{array}{l}\text { Weight } \\
\text { (mg.) }\end{array}$} & \multicolumn{2}{|c|}{$\begin{array}{l}\text { Quantity of flavin } \\
\text { compound }(\gamma)\end{array}$} \\
\hline & & $\begin{array}{l}\text { Total } \\
\text { weight }\end{array}$ & Per piece & Per piece & $\begin{array}{c}\text { Per } 1 \text { g. of } \\
\text { fresh material }\end{array}$ \\
\hline Whole eyeball & 10 & 1800.2 & 180.0 & 6.62 & 36.16 \\
\hline Cornea & 300 & 920.0 & $3.1^{*}$ & $0.007 *$ & 2.27 \\
\hline $\begin{array}{l}\text { Anterior } \\
\text { aqueous }\end{array}$ & 170 & 6139.8 & $* *$ & 0 & 0 \\
\hline Lens & 180 & 4859.3 & 27.0 & 0 & 0 \\
\hline $\begin{array}{l}\text { Iris and } \\
\text { ciliary body }\end{array}$ & 160 & 447.0 & 2.8 & 0.52 & 188.41 \\
\hline Vitreous & 144 & 7023.7 & $* *$ & $* *$ & 0.04 \\
\hline Retina & 290 & 3756.7 & 12.9 & 0.01 & 0.79 \\
\hline Choroid & 30 & 79.8 & 2.7 & 5.83 & 2186.02 \\
\hline Sclera & 229 & 1742.1 & $7.6^{*}$ & 0.03 & 3.67 \\
\hline
\end{tabular}

* The figures are not exact as the materials could not totally be cut out.

** Not estimated as the materials were obtained only partially.

2. Difference in different species of frogs. Since it was difficult to obtain Rana nigromaculata in winter, Bufo vulgaris formosus was used in some experiments, and it was found that the results differed markedly from that of Rana nigromaculata. Investigations were therefore made on vasious frogs.

Table 2

\begin{tabular}{|c|c|c|c|c|c|c|}
\hline & \multirow{2}{*}{$\begin{array}{c}\text { Number } \\
\text { of } \\
\text { preces }\end{array}$} & \multicolumn{2}{|c|}{$\begin{array}{c}\text { Weight } \\
\text { (mg.) }\end{array}$} & \multicolumn{2}{|c|}{$\begin{array}{l}\text { Quantity of flavin } \\
\text { compound }(\gamma)\end{array}$} \\
\hline & & & $\begin{array}{l}\text { Total } \\
\text { weight }\end{array}$ & Per piece & Per piece & $\begin{array}{c}\text { Per } 1 \text { g. of } \\
\text { fresh material }\end{array}$ \\
\hline \multirow{4}{*}{$\begin{array}{c}\text { Bufo } \\
\text { vulgaris } \\
\text { formosus }\end{array}$} & $\begin{array}{c}\text { Whole } \\
\text { eyeball }\end{array}$ & 12 & 6338.9 & 528.2 & 0.77 & 1.44 \\
\hline & $\begin{array}{l}\text { Iris and } \\
\text { ciliary body }\end{array}$ & 18 & 239.4 & 13.3 & 0.50 & 32.41 \\
\hline & Retina & 115 & 2983.3 & 25.9 & 0.06 & 2.10 \\
\hline & Choroid & 77 & 1005.6 & 13.1 & 0.04 & 3.38 \\
\hline \multirow{4}{*}{$\begin{array}{c}\text { Rana } \\
\text { catesbiana }\end{array}$} & $\begin{array}{c}\text { Whole } \\
\text { eyeball }\end{array}$ & 9 & 3576.8 & 397.4 & 4.00 & 10.07 \\
\hline & $\begin{array}{l}\text { Iris and } \\
\text { ciliary body }\end{array}$ & 40 & 445.9 & 11.2 & 0.85 & 76.48 \\
\hline & Retina & 50 & 1890.6 & 37.8 & 0.05 & 1.29 \\
\hline & Choroid & 40 & 539.5 & 13.5 & 2.68 & 198.30 \\
\hline \multirow{4}{*}{$\begin{array}{c}\text { Rana } \\
\text { rugosa }\end{array}$} & $\begin{array}{l}\text { Whole } \\
\text { eyeball }\end{array}$ & 31 & 1150.1 & 37.1 & 0.36 & 9.76 \\
\hline & $\begin{array}{l}\text { Iris and } \\
\text { ciliary body }\end{array}$ & 52 & 99.5 & 1.9 & 0.13 & 66.72 \\
\hline & Retina & 43 & 147.9 & 3.4 & 0.03 & 7.58 \\
\hline & Choroid & 35 & 13.0 & 3.7 & 0.19 & 517.50 \\
\hline
\end{tabular}


Table 2 (Cntinued)

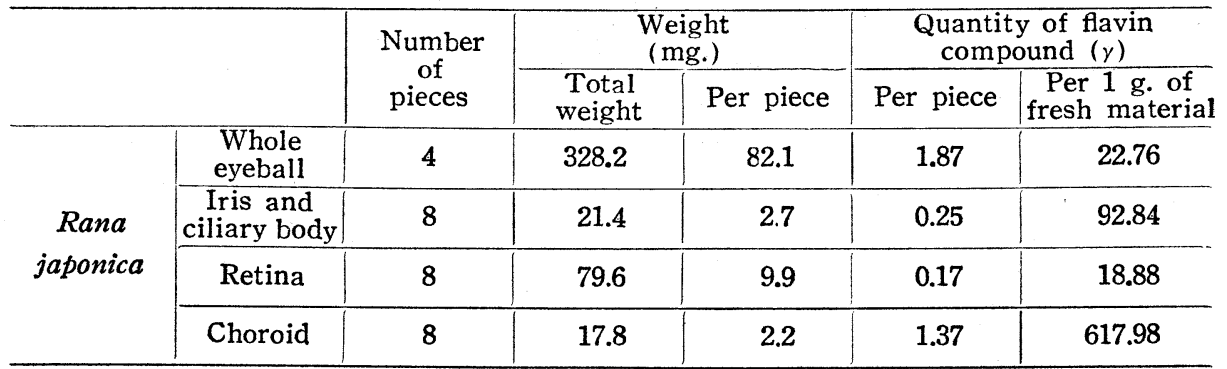

The results are summarized in table 2 . We see that the distribution varies considerably in various species. However, a phenomenon common in all cases was that most of the flavin compound was contained in the choroid, iris and ciliary body, and a small amount in the retina. This characteristic was most marked in Rana nigromaculata, and least so in Bufo vulgaris formosus.

3. Observations at different seasons. The quantity of flavin compound in the eye of Rana nigromaculata in summer was compared with that during hibernation. Distribution of the total quantity of flavin compounds in the eye of the latter is shown in table 3.

Table 3

\begin{tabular}{c|c|c|c|c|c}
\hline \hline & \multirow{2}{*}{$\begin{array}{c}\text { Number } \\
\text { of } \\
\text { pieces }\end{array}$} & \multicolumn{2}{|c|}{$\begin{array}{c}\text { Weight } \\
\text { (mg.) }\end{array}$} & \multicolumn{2}{c}{$\begin{array}{c}\text { Quantity of flavin } \\
\text { compound }(\gamma)\end{array}$} \\
\cline { 3 - 6 } & $\begin{array}{c}\text { Tolal } \\
\text { Weight }\end{array}$ & Per piece & Per piece & $\begin{array}{c}\text { Per 1 g. of } \\
\text { fresh material }\end{array}$ \\
\hline Whole eyeball & 6 & 543.2 & 90.53 & 3.47 & 38.36 \\
\hline $\begin{array}{c}\text { Iris and } \\
\text { ciliary body }\end{array}$ & 40 & 98.2 & 2.46 & 0.57 & 230.01 \\
\hline Retina & 90 & 1072.5 & 11.92 & 0.01 & 1.12 \\
\hline Choroid & 20 & 45.5 & 2.28 & 4.65 & 2039.52 \\
\hline
\end{tabular}

Since the frogs were small, no comparison could be drawn per one eye, but there was not much difference per unit weight. It seemed that the quantity of flavin compound contained in the choroid of frogs during hibernation was a little less, but generally no considerable difference was observed.

4. Change in distribution of flavin compound in the eye when exposed to light. With Rana nigromaculata, the quantity of flavin compound contained in parts of the eye separated in a dark room and that separated in a lighted room showed no differences except in the retina.

The quantity of flavin compound contained in the retina obtained under a red electric lamp from an eye of a frog kept in a dark room was compared with that of the other eye after an hour in a lighted room. As is shown in table 4, the quantity was 3-5 times as large in the latter than in the former.

From this fact, it may be considered that flavin compound moves from 
Table 4

\begin{tabular}{c|c|c|c|c|c|c|c}
\hline \hline & \multirow{2}{*}{$\begin{array}{c}\text { Number } \\
\text { of } \\
\text { retina }\end{array}$} & \multicolumn{2}{|c|}{$\begin{array}{c}\text { Weight } \\
\text { (mg.) }\end{array}$} & \multicolumn{2}{c}{$\begin{array}{c}\text { Quantity of flavin } \\
\text { compound }(\gamma)\end{array}$} \\
\cline { 5 - 8 } & $\begin{array}{c}\text { Total } \\
\text { weight }\end{array}$ & Per piece & Per piece $\begin{array}{c}\text { Per 1 g. of } \\
\text { fresh material }\end{array}$ \\
\hline \multirow{2}{*}{ I } & $\begin{array}{c}\text { Dark } \\
\text { Light }\end{array}$ & 100 & 1395.5 & 13.9 & 0.010 & 0.72 \\
& 100 & 1355.0 & 13.6 & 0.035 & 2.58 \\
\hline \multirow{2}{*}{ II } & Dark & 60 & 783.3 & 13.1 & 0.013 & 1.02 \\
& Light & 60 & 745.4 & 12.4 & 0.060 & 4.83 \\
\hline \multirow{2}{*}{ III } & Dark & 80 & 1004.3 & 12.6 & 0.006 & 0.50 \\
& Light & 80 & 1011.6 & 12.6 & 0.038 & 3.00 \\
\hline
\end{tabular}

choroid to retina. It is known that there is a phenomenon of pigment movement in the retina of frogs, that is, with light adaptation, the pigment moves from choroid to retina. Hence, the following experiment was conducted to examine the relationship of the movement of flavin compound to that of pigment.

In regard to 50 frogs under light adaptation, 50 retinae from one eye of each frog were obtained and the quantity of flavin compound in them was determined. The other 50 retinae were placed on hard paper, the pigment attached to the posterior part of the retina was removed mechanically with wet filter paper, and the quantity of flavin compound in them was determined. The results are shown in table 5 . When pigment was removed, the quantity of flavin compound contained in the retina under light adaptation differed little from that in the retina under dark adaptation. From this, it may be considered that flavin compound emigrated in company with the pigment.

Table 5

\begin{tabular}{c|c|c|c}
\hline \hline & $\begin{array}{c}\text { Number } \\
\text { of } \\
\text { retina }\end{array}$ & $\begin{array}{c}\text { Weight } \\
\text { (mg.) }\end{array}$ & $\begin{array}{c}\text { Quantity of flavin } \\
\text { per 1 g. of fresh } \\
\text { materal }\end{array}$ \\
\hline $\begin{array}{c}\text { Control } \\
\begin{array}{c}\text { Retina from which } \\
\text { pigment is removed }\end{array}\end{array}$ & 50 & 665.2 & 4.90 \\
\hline $\begin{array}{c}\text { Control } \\
\text { Retina from which } \\
\text { pigment is removed }\end{array}$ & 50 & 489.7 & 1.02 \\
\hline
\end{tabular}

5. Is the flavin compound in the ey free riboflavin? First, the solubility of the flavin compound in benzyl alcohol was examined, that is, the extract solution of retina was extracted three times with benzyl alcohol and the flavin compound remaining in the solution was estimated by the lumiflavin fluorescence method. All the flavin compounds in the frogs' eye were soluble in benzyl alcohol, except that in the retina which was not soluble. Moreover, when takadiastase was added to the extract of the retina and allowed to act on it, the flavin compound became soluble in benzyl alcohol. Therefore it may be considered that an ester of riboflavin exists in the retina. 
Next, paper chromatography was conducted with flavin compounds in retina, choroid, iris and ciliary body. This showed that the flavin compounds in the choroid, iris and ciliary body were all free riboflavin, while that in the retina was all FMN. As control, FAD prepared from the livers of pigs and FMN obtained from it by hydrolysis with trichloroacetic acid were used, and the above result was confirmed.

It has been said that the retina is an organ with an exceedingly high metabolism and when exposed to light this becomes more marked. In order to avoid the influence of light, the estimations were made in a dark room throughout the whole process, from enucleation of the retina to the completion of extraction, but the results were in all cases the same. In order to remove the effect of enzymatic reaction during the time from enucleation to extraction, the retinae were placed in warm water at $80^{\circ} \mathrm{C}$. immediately after enucleation and paper chromatography was conducted, but the results were the same. This was most clearly seen in the retina of Bufo vulgaris formosus which contains a comparatively large amount of flavin compound.

\section{CONCLUSION}

Flavin compound in the eye of Rana nigromaculata concentrates in the choroid, iris and ciliary body, and is not much contained in the other parts. In the retina its amount is also low. No marked seasonal change is observed.

The amount and distribution of flavin compound in the eye vary considerably in different species of frogs. It is, however, common to all frogs that it is present chiefly in the choroid, iris and ciliary body and a little in the retina.

The retina under light adaptation contains 3 to 5 times as much flavin compound as that under dark adaptation. Probably it moves from the choroid into the bacillary layer of the retina in company with the pigment.

The flavin compound in the retina is an ester while those in the other parts of the eye are free riboflavin.

With regard to the significance of flavin compound on the visual sense, it may be considered that it acts as a co-enzyme, at least on the rods and cones, not only by its fluorescence, as the previous investigators alleged.

The author wishes to thank Prof. Kazuo Hotta and late Prof. Minoru Nakashima for their kind advices in this study.

\section{REFERENCES}

1. V. Euler, H. AND Adler, E. Z. physiol. Chem. 223: 105, 1934. $228: 1,1934$.

2. Karrer, P. AND Fritzsche, H. Helv. chim. Acta 18: 911, 1935.

3. Brunner, O. And Baroni, E. Sitzsber. Akad. Wiss. Wien Math. Naturwiss. Kl. 11. b. $145: 484,1936$.

4. V. Euler, H. AND AdLER, E. Nature 141: 790, 1938.

5. SÜllmanN, E. Kl. Wschr. $17: 1157,1938$.

6. NAKASHIMA, M. Bioch. Z. $204: 479,1929$.

7. KUBOWITZ, F. Bioch. Z. 204 : 475, 1929.

8. Fi.eischmanN, W. AND PICHLER, E. Kl. Wschr. 17 : 314. 1938. 
9. MANABE, M. Nihon Gankagakukai Zasshi (Japanese Journal of Ophthalmology) 44: $1149,1171,1945$ (Japanese).

10. TAKADA, R. AND NAGAMURA, M. Bitamin-Kenkyu (Study of Vitamin) 47, 1946 (Japanese).

11. YAGI, K. AND ISHIGURO, I. Igaku to Seibutsugaku (Medicine and Biology) 17: 105, 1950 (Japanese).

12. EMMERIE, A. Nature $141: 416,1938$.

13. CRAMMER, J. L. Nature 161: 349, 1948.

14. YAGI, K. Seikagaku (Juornal of Japanese Biochemical Society) 22: 240, 1950 (Japanese). 